\title{
Stories in collision
}

\author{
Granta: Medicine \\ Issue 120 \\ Summer 2012 \\ Granta Publications
}

$\mathrm{W}$ hy would Granta, a literary quarterly, publish an issue called Medicine? At the September launch in London, editor John Freeman described the collection as the collision between the stories that we tell about our lives and the stories that our bodies tell. Rather than being prescriptive, he sees it as opening discussion.

The first story, "Grand Rounds" by Chris Adrian, does exactly that. It opens the discussion through the narrator's lecture on narrative medicine. Incapable of delivering on his promise to talk about why stories matter, "why people I respect and trust insist that a facility in telling and listening to stories makes for a better practice of medicine," he excuses himself as "more than a little post-call." Instead he tells a story, which makes his point better than any lecture could. "Grand Rounds" has a strong voice, experimentation and a moving story within a story that demonstrates the premise. I wonder, though, if I also like it because it shows a doctor as vulnerable.

One of three doctors contributing to Medicine, Adrian is the author of three novels. The other fourteen contributors are writers of fiction and poetry. I was surprised by some of the editor's choices. For example, Alice Munro is included but Dr. Vincent Lam is not. Eight of the contributors work in the United States. Despite 2012 being the Year of the Short Story in England, no short stories by UK writers are included.

The nonfiction "Hardy Animal," by award-winning novelist M.J. Hyland (her most recent novel is This Is How) is the signature piece of the collection, as she tells both her life story and the story of what multiple sclerosis does to her body. The disease affects her very identity: "MS had ruined the good story: the clever, slum survivor narrative." It also

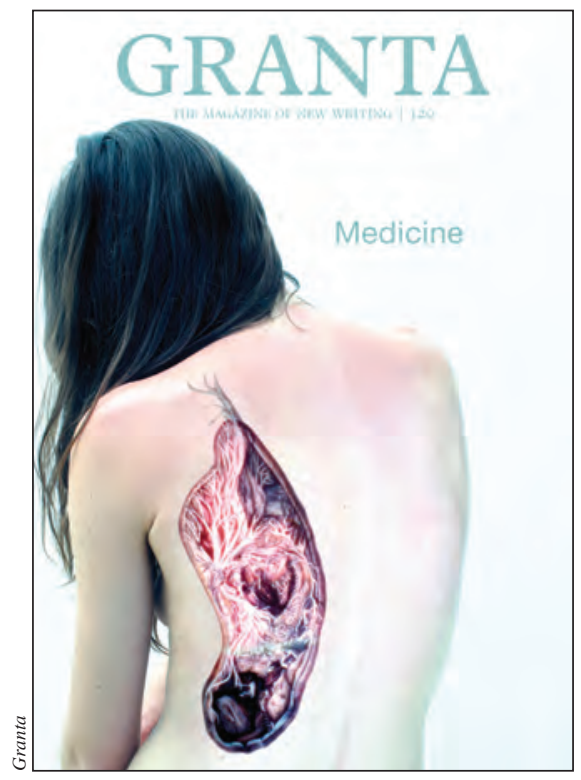

ruins her writing hand, disabling it after a couple of hours of writing. Her experiment with voice-recognition software fails: "Using speech to write was like doing a jigsaw with mittens on."

There are some parallels in the collection. Terence Holt, the author of the story collection, In the Valley of the Kings, writes about a resident during a shift in an emergency department in his story, "The Perfect Code." Through the first-person narrator, we see the thought processes behind decisions made in a crisis. This story contrasts nicely with the memoir by the Bosnian author of Sarajevo Blues, Semezdin Mehmedinovic. "My Heart" begins: "Today, it seems, was the day I was meant to die." He doesn't die, but he grips the reader's interest. Of the ambulance attendants, he writes, "I had never experienced such an aggressive assault on my privacy." What is a necessary intervention in Holt's story is an assault in "My Heart."

Like Hyland, Mehmedinovic tries to assert his identity against this attack on his body through his knowledge, referring to Christopher Hitchens, a Chilean miner, Somalia, 1939, 1992, Kalashnikovs. Irritatingly, he identifies the staff by type: "an African Muslim girl," the surgeon who "was Indian," a "young
African" radiologist. He mentions several times that the American hospital staff have trouble with his foreign name.

Other pieces in the collection also deal with the cross-cultural aspect of medical care, such as Gish Jen's story, "The Third Dumpster," in which the Chinese mother does not want to go to a nursing home because she feels one of her sons should take her home to live with them. More moving is the non-fiction piece by physician Ike Anya, "People Don't Get Depressed in Nigeria." Anya now works in London, but this piece is about his time in rural Nigeria, dealing with the vagaries of foreign medical aid. Anya co-edited an anthology of new Nigerian writing, the Weaverbird Collection.

Granta has been publishing since 1979 as a literary quarterly for new writing. It evolved from The Granta, a publication by students of Cambridge University, founded in 1889. Each print issue includes fiction, nonfiction (reportage, memoir) and photography, and is accompanied by an online edition. In addition, there is a daily online edition, New Writing (www.granta.com/New-Writing). In the case of Medicine, the online edition offers four additional narratives and an essay by neurosurgeon and writer, Henry Marsh. Oddly, the print edition gives no indication of a bonus online.

The most disquieting memoir is Alice Munro's "Night," which reads like a short story. At first, it appears to be about a girl's insomnia. On closer reading, it has to do with expectations and fear. The father listens as the "truth was told with only the slightest modification." He listens, and in so doing, heals her. That is what Granta's collection Medicine does - it teaches us (humorously and passionately) to listen to the story we are being told.

\section{Debra Martens MA \\ Editor \\ Canadian Writers Abroad \\ London, UK}

CMAJ 2012. DOI:10.1503/cmaj.121543 